\title{
Technology Pathways and Economic Analysis for Transforming High Temperature to Low Temperature District Heating Systems
}

\author{
Pedro Durán (D), Herena Torio *(D), Patrik Schönfeldt (D), Peter Klement $\mathbb{D}^{\text {, }}$, Benedikt Hanke $\mathbb{D}_{\text {, }}$ \\ Karsten von Maydell (D) and Carsten Agert (D)
}

Citation: Durán, P.; Torio, H.;

Schönfeldt, P.; Klement, P.; Hanke, B.; von Maydell, K.; Agert, C. Technology Pathways and Economic Analysis for Transforming High Temperature to Low Temperature District Heating Systems. Energies 2021, 14, 3218. https://doi.org/10.3390/en14113218

Academic Editor: David Borge-Diez

Received: 26 March 2021

Accepted: 18 May 2021

Published: 31 May 2021

Publisher's Note: MDPI stays neutra with regard to jurisdictional claims in published maps and institutional affiliations.

Copyright: (c) 2021 by the authors. Licensee MDPI, Basel, Switzerland. This article is an open access article distributed under the terms and conditions of the Creative Commons Attribution (CC BY) license (https:// creativecommons.org/licenses/by/ $4.0 /)$.
DLR Institute of Networked Energy Systems, Carl-von-Ossietzky-Str. 15, 26129 Oldenburg, Germany; pedro.duran@dlr.de (P.D.); patrik.schoenfeldt@dlr.de (P.S.); Peter.klement@dlr.de (P.K.); benedikt.hanke@dlr.de (B.H.); karsten.maydell@dlr.de (K.v.M.); Carsten.Agert@dlr.de (C.A.)

* Correspondence: herena.torio@dlr.de

\begin{abstract}
There are 1454 district heating systems in Germany. Most of them are fossil based and with high temperature levels, which is neither efficient nor sustainable and needs to be changed for reaching the 2050 climate goals. In this paper, we present a case study for transforming a high to low temperature district heating system which is more suitable for renewable energy supply. With the Carnot Toolbox, a dynamic model of a potential district heating system is simulated and then transformed to a low temperature supply. A sensitivity analysis is carried out to see the system performance in case space constrains restrict the transformation. Finally, an economic comparison is performed. Results show that it is technically possible to perform the transformation until a very low temperature system. The use of decentralized renewable sources, decentralized heat storage tanks and the placement of a heat pump on each building are the key points to achieve the transformation. Regarding the sensitivity analysis, the transformation is worth doing until the seasonal storage and solar collector field sizes are reduced to $60 \%$ and $80 \%$ of their values in the reference case, respectively. The economic analysis shows, however, that it is hard for highly efficient low temperature renewable based heat networks to compete with district heating systems based on a centralized fossile CHP solution. Thus, though the presented transformation is technically possible, there is a strong need to change existing economic schemes and policies for fostering a stronger promotion of renewable energy policies in the heat sector.
\end{abstract}

Keywords: low temperature district heating system; district heating retrofit; heating sector decarbonisation; dynamic district heating modelling; power to heat; levelized cost of heat

\section{Introduction}

The "Climate Action Plan 2050" from the German Federal Government is aiming for a reduction of greenhouse gases (GHGs) emission between $85 \%$ and $95 \%$ by 2050 compared to 1990 levels in order to keep the increase of the global average temperature below $2{ }^{\circ} \mathrm{C}$ [1]. Heat demands for space heating (SH) and domestic hot water (DHW) account for $469 \mathrm{TWh} / \mathrm{a}$ in Germany and represent 32\% of the total final energy consumption [2] (p. 3). However, whereas the renewable energy share in the electrical power sector amounts to $42.1 \%$ of the production, this share represents merely $14.5 \%$ in the heating sector $[3,4]$. Therefore power-to-heat strategies are a promising filed for implementing sector coupling solutions that reduce the climate footprint of the energy system [5].

Low temperature district heating systems (LTDH), so called Low-Ex networks or 4th generation district heating systems [6] are identified as a key milestone in the "Climate Action Plan 2050" [1]. Such systems focus on (i) reducing the supply and return temperatures allowing a higher integration of renewable energy sources in the heat supply, (ii) integrating decentralized supply sources and (iii) smart control systems enabling sector 
coupling and bidirectional supply and demand within the network [7]. Thus, LTDH address clearly the two key points that the German climate plan proposes [1]: (i) increasing the share of energy coming from renewable sources and (ii) improving sector efficiency. The design and performance of such 4th generation district heating systems is other than trivial, as it requires the optimal interplay of several low temperature systems and components. Wang et al. [7] investigate the influence of the district size, the retrofitting stage of buildings and the system configuration on the performance of the DHS. They identify the specific storage volume (as related to the collector area) to be the most important parameter for an advantageous system performance. Increasing the storage size leads to an improved performance until a threshold is reached beyond which bigger storages do not lead to higher solar fractions. The optimal storage size, however, is dependent on the district demand characteristics [7]. Hsieh et al. [8] show the importance of the storage size and position within such solar LTDH systems in order to achieve reasonable solar fractions. Analysing a case study in Switzerland they show that system performance is best, both in energy and economic terms, when the system is designed for a solar fraction of 40 to $50 \%$.

In Germany there were 1454 district heating systems installed in 2019, representing $13.8 \%$ of the heating sector [9], with $86 \%$ of them having a pipe length greater than $100 \mathrm{~km}$ [10] (p. 6). However, $83 \%$ of the heat supplied in such systems comes from combined heat and power plants (CHP) [11] fuelled by coal (31\%), lignite (12\%), natural gas $(36 \%)$, renewables $(13 \%)$ and others $(8 \%)$ [12] (p. 39). CHP units supply heat at temperatures around $80{ }^{\circ} \mathrm{C}$. Thus, in Germany most of existing systems are high temperature district heating systems (HTDH) and fossil fuel based. In order to reach the proposed reduction in GHG emission, transforming these fossil fuel based district heating from high temperature to low temperature is of great advantage. This transformation allows integrating renewable low temperature sources into the heat supply while avoiding the network installation costs, which are major burden for installing district heating systems [13]. Figure 1 shows the implementation possibilities for LTDH systems.

\begin{tabular}{|c|c|c|}
\hline Existing DH System (HT) & Retrofitted DH System $(H T \Rightarrow L T)$ & New DH System (LT) \\
\hline $\begin{array}{l}\text { Network design } \\
\text { Constrained }\end{array}$ & $\begin{array}{l}\text { Network design } \\
\text { Constrained }\end{array}$ & $\begin{array}{l}\text { Network design } \\
\text { Flexible }\end{array}$ \\
\hline $\begin{array}{l}\text { Technology design } \\
\text { Constrained } \\
\text { (centralized } \mathrm{CHP} / \text { gas } \\
\text { boiler) }\end{array}$ & $\begin{array}{l}\text { Technology design } \\
\text { Semi flexible }\end{array}$ & $\begin{array}{c}\text { Technology design } \\
\text { Fully flexible } \\
\text { ((de)centralized heat sources, } \\
\text { centralized seasonal storage) }\end{array}$ \\
\hline
\end{tabular}

Figure 1. Implementation possibilities for LTDH systems.

LTDH systems can be implemented as a new system or by retrofitting an existing high temperature system. In a new system both network and technological design, are flexible since the system is specifically built to operate with low temperatures. In a retrofitted system, on the contrary, there is already a district network built for operating at high temperatures, implying several constrains to changes in the network design and its further adaptations (e.g., pipe diameter, pipe insulation, ...). Yet, in such a system incorporating new technologies that are compatible with the district network is possible (semi-flexible technology design).

The case study selected here is the Energetic Neighbourhood Quarter (ENaQ) project [14], where a living area and the energy system required to supply its demands is being developed at the former military air base in Oldenburg, Germany. Since thermal demands dominate the building energy demands in living quarters, the main focus of the present work is the thermal behavior of the heat network and building systems. Thus, the models developed for the analysis address relevant heat transfer processes in the energy system. Pressure losses as well as the hydraulic behavior of the system are out of scope in this work and are not analysed in detail. The core of this work is the possible transformation of a high temperature heat 
network to operate under a low temperature regime. For this, a low temperature system is implemented with the help of suitable building technologies (e.g., heat pumps, solar thermal collectors, storages) and its thermal performance is compared to the starting high temperature network system.

Section 1.1 shows the main challenges related to such a transformation for an existing high temperature heat network. Section 2 introduces the case study used to analyze the transformation. Section 3 shows the simulation tools and models developed for analyzing the case study and the transformation for HTDH to a LTDH System. The key performance indicators used to compare the performance of the two network layouts are shown in Section 3.4. Section 3.5 shows the main parameters varied within the LTDH system in order to improve its performance. Sections 4 and 5 present the main results and conclusions obtained from the analysis.

\subsection{Challenges for Reducing a District Heating System Temperature}

There are two main challenges in order to successfully achieve a reduction of the network temperature. The first challenge addresses the return temperature. It has been studied that the only way to reduce a district network temperature is by a reduction of the return temperature which leads to a reduction of the supply temperature and not vice versa $[15,16]$. Therefore, technical solutions to reduce the return temperature of the district network are required. The second challenge concerns the water velocity inside the district network. Equation (1) shows the transported heat $\dot{Q}_{\text {transported }}$ through a district network which equals the product between the mass flow of the water inside the network $\dot{m}_{w}$, the specific heat $c_{p w}$ and the temperature difference $\left(T_{\text {supply }}-T_{\text {return }}\right)$. Supply temperature means water going from the heat source to the buildings while return temperature means water returning from the buildings to the heat sourc

$$
\dot{Q}_{\text {transported }}=\dot{m}_{\mathrm{w}} c_{\mathrm{pw}}\left(T_{\text {supply }}-T_{\text {return }}\right)
$$

There is a trade off between the mass flow and the temperature difference $T_{\text {supply }}-$ $T_{\text {return. }}$. If the aim is to supply the same amount of energy trough the district network to the buildings, then the mass flow needs to increase when the temperature difference reduces. The mass flow is directly proportional to the water velocity inside the district network and was designed to operate with a high temperature difference. A reduction of this difference means to overcome the maximum water velocity for which the network was originally designed. The maximum water velocity differs from system to system but it in the range between 2.0 and $2.5 \mathrm{~m} / \mathrm{s}$ [17] (p. 108) [18] (p. 20).

\section{The ENaQ Case Study: High Temperature District Heating Case (HTDH)}

This section presents the main characteristics of the neighbourhood and district network used in this paper as case study for analyzing the feasibility of the transformation. Figure 2 shows the projected district network on the ENaQ project [14]. The project incorporates an energy center, indicated by the blue dot which represents the centralized CHP unit together with a gas boiler as back up. Buildings 1 to $3 \mathrm{~b}$ are residential buildings for multi family houses, while building 4 is a student house. Building 5 is a hall where a canteen and some apartments are. 


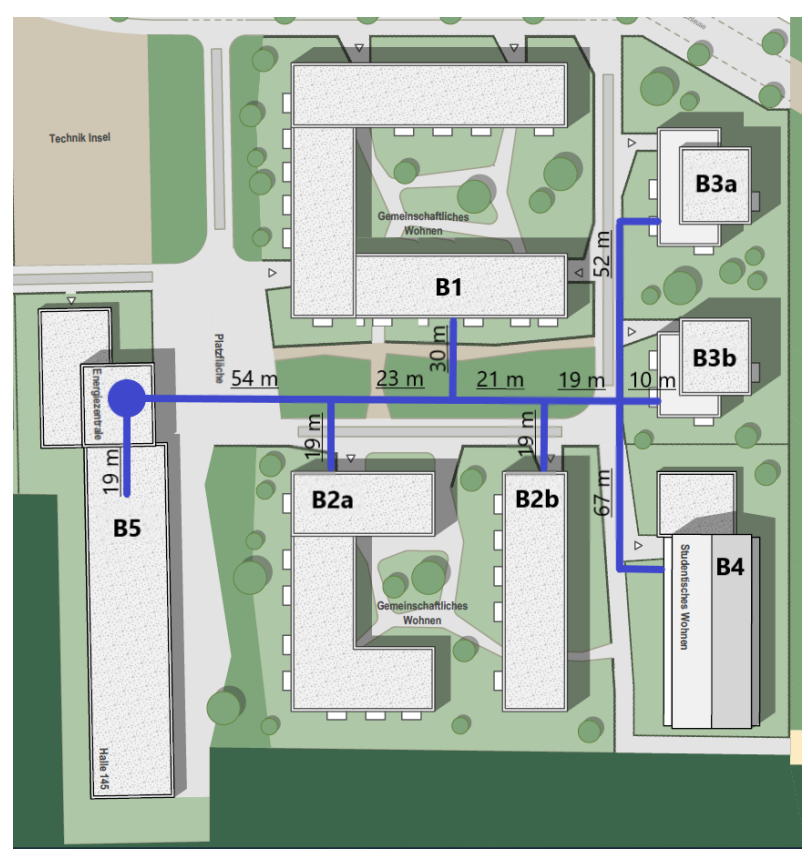

Figure 2. ENaQ district heating system (Figure obtained from GSG Oldenburg (Germany)).

The future ENaQ domestic hot water and space heating energy demands are presented in Table 1.

Table 1. Area, space heating and domestic hot water demand for each building in ENaQ.

\begin{tabular}{|c|c|c|c|}
\hline Building & Area $\left(m^{2}\right)$ & SH Demand $\left(\mathrm{kWh} / \mathrm{m}^{2} \mathrm{a}\right)$ & DHW Demand $\left(\mathrm{kWh} / \mathrm{m}^{2} \mathrm{a}\right)$ \\
\hline B1 & 3215 & 29.5 & 12.5 \\
\hline B2a & 1942 & 30.4 & 12.5 \\
\hline $\mathrm{B} 2 \mathrm{~b}$ & 1092 & 29.4 & 12.5 \\
\hline B3a & 1037 & 25.8 & 12.5 \\
\hline $\mathrm{B} 3 \mathrm{~b}$ & 890 & 26.3 & 12.5 \\
\hline B4 & 2054 & 36.4 & 12.5 \\
\hline B5 & 1112 & 117.8 & 12.5 \\
\hline
\end{tabular}

With these data, hourly profiles for SH and DHW were generated for each building. In both HTDH and LTDH models developed, building 3b was selected to model and scaling the heat demands, since it had the highest peak load per square meter. Thus, heat demands to be transported through the network were never underestimated.

\section{Methodology}

The software used for ENaQ simulations was the Carnot Toolbox [19] which was under the MATLAB-Simulink environment. It allowed the dynamic simulation of thermal systems, where components such as solar collectors, storage tanks or heat pumps could be dragged and dropped to a main frame and then connected to each other to create more complex systems. For modelling the $\mathrm{ENaQ}$ neighbourhood $\mathrm{ENaQ}$ the following simplifications were made: (i) single building model was used to represent the district demand. This demand was then scaled to the district network; (ii) the district network was represented as a two single pipes (supply and return) connecting the single building to the seasonal storage.

\subsection{District Network Model in the Carnot Toolbox}

The role of the district network is to connect all the buildings with either (i) the CHP unit in the HTDH model or (ii) to the centralized seasonal water storage tank, which is 
used to store the energy surplus produced by the buildings in summer (charging) and use it in winter (discharging).

For representing the district network in a two single pipes system, there were two factors that needed to be calculated, the equivalent length $L_{\mathrm{eq}}$ and equivalent heat transfer unit $U_{e q}$. This allowed modelling the dynamic behavior of the network with a small amount of information: the lengths of each section of the network, the demand share of each building and the dimensions (inside and outside insulation radius) of the main pipe.

The equivalent length was calculated following the method presented by Heimrath [20] (p. 130). Equation (2) shows the calculation, where each $L_{i}$ is the segment of the network where the mass flow $m_{i}$ circulated. The calculation of each mass flow was based on the share of the demand of each building. This calculation could only be done if the lengths of each segment were in the same order of magnitude.

$$
L_{\mathrm{eq}}=\frac{\sum_{i} L_{i} \dot{m}_{i}}{\sum_{i} \dot{m}_{i}}
$$

The calculation of the equivalent heat transfer unit was done by adding the $U_{i}$ of each segment as Equation (3) shows where $k$ represents the thermal conductivity of the insulation and $r_{\text {out } i}$ and $r_{\text {in } i}$ represent the outer and inner radius of the insulation for each segment.

$$
U_{\mathrm{eq}}=\sum_{i} U_{i}=\sum_{i} \frac{2 \pi k}{\ln \frac{r_{\mathrm{out}, i}}{r_{\mathrm{in}, i}}}
$$

The starting point for calculating every $r_{\text {out,i }}$ and $r_{\text {in }, i}$ was the main pipe which was provided by the TUM study [21] ( $r_{\text {out, } 1}$ and $\left.r_{\text {in,1 }}\right)$ From that point every $r_{\text {in }, i}$ was calculated according to the share of mass flow that circulated in the pipe $i$. For $r_{\text {out }, i}$ the calculation was done to always maintain the ratio $r_{\text {out }, 1} / r_{\text {in, } 1}$.

With these parameters calculated it was possible to obtain the district network losses in a two single pipes system according to Equation (4).

$$
Q_{\text {loss }}=U_{\text {eq }} L_{\mathrm{eq}} \Delta T
$$

With the method proposed above an equivalent length of $L_{\mathrm{eq}}=41.12 \mathrm{~m}$ and an equivalent heat transfer unit of $U_{\mathrm{eq}}=3.53 \mathrm{~W} / \mathrm{mK}$ were obtained to represent the heat network at the ENaQ neighbourhood.

To use this method it was important to assume that the supply temperature in every section of the network was the same. That means that for each supply pipe, the temperature difference between the section and the soil was the same $\left(\Delta T_{\text {supply, } 1}=\Delta T_{\text {supply, } 2}=\right.$ $\Delta T_{\text {supply }, i}=\Delta T_{\text {supply }}$ ). The same principle applied for the return temperature.

The last point to address was the representation of a bidirectional flow model, since the Carnot Toolbox was not able to work with negatives mass flows. To cope with this problem a four line pipe system was implemented on the Carnot Toolbox. As shown in Figure 3, there were two pipes for charging and two for discharging, each of them with a bypass. Depending on whether the seasonal storage was being charged or discharged, only the two pipes for the corresponding process were considered for calculating the losses. 


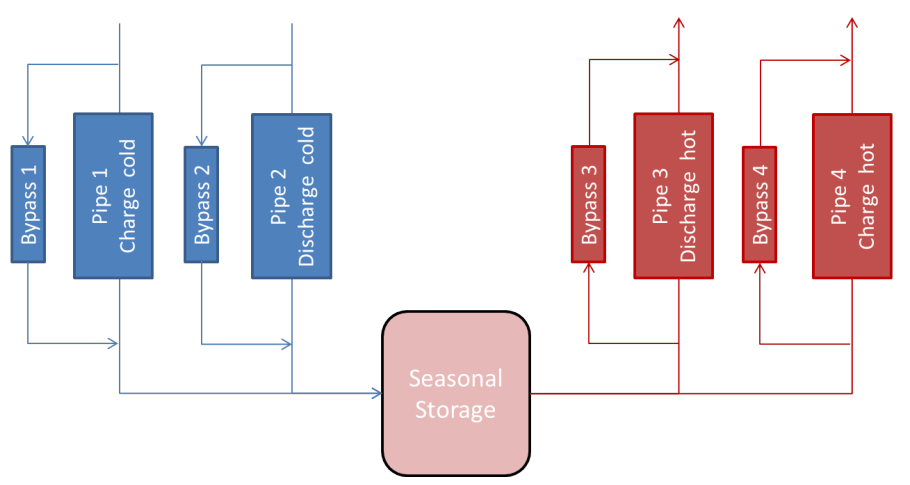

Figure 3. Four pipes network to represent a bidirectional mass flow system in the Carnot Toolbox.

\subsection{ENaQ Starting Case: The Model for the HTDH}

Figure 4 shows a scheme of the HTDH model.

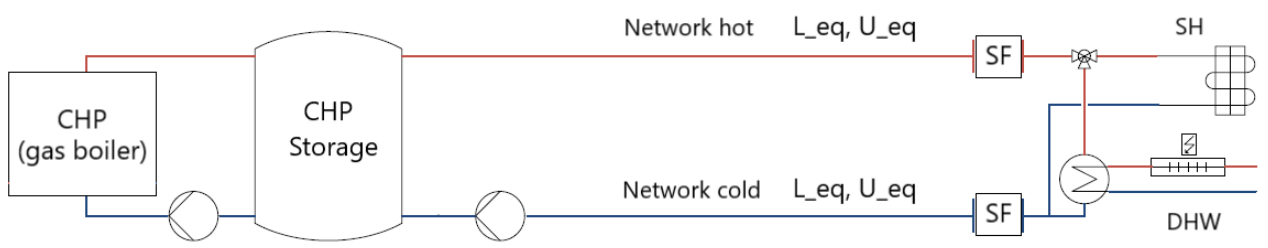

Figure 4. ENaQ HTDH model.

The CHP had a thermal output of $100 \mathrm{~kW}_{\text {th }}$ while the gas boiler had $420 \mathrm{~kW}_{\text {th }}$ which was the highest peak load of the system in winter. This model considered that both heat sources supply water at $80{ }^{\circ} \mathrm{C}$ and had a thermal efficiency of $94.2 \%$. The thermal efficiency of the CHP was calculated without the gas used for electricity production (nominal values were: $177 \mathrm{~kW}$ of natural gas produce $67 \mathrm{~kW}_{\mathrm{el}}$ and $100 \mathrm{~kW}_{\mathrm{th}}$ ). The centralized heat storage had a size of $9 \mathrm{~m}^{3}$ and the control strategy was adjusted for turning the CHP (or gas boiler) on when the temperature of the upper node fell below $70{ }^{\circ} \mathrm{C}$ until this temperature reached $80{ }^{\circ} \mathrm{C}$ again. The heat network was simulated following the approach described in Section 3.1.

\subsection{ENaQ Retrofitted: The LTDH Case}

$\mathrm{ENaQ}$ retrofitted scenario was modeled by taking from one side the network topology and district demands from ENaQ starting model and merging them with a building model having several decentralized renewable building technologies. For performing the district heating system transformation, the seasonal storage was placed where the CHP previously was, which had a volume of $6198 \mathrm{~m}^{3}$. Building $3 \mathrm{~b}$ was the one use to scale heat demands. To model its behavior in detail, a solar collector area of $54 \mathrm{~m}^{2}$, a buffer storage tank size of $63.72 \mathrm{~L}$ and an on-demand storage size of $31.86 \mathrm{~L}$. Specific values used for determining the size of these components are shown in Appendix B. The seasonal tank had a nominal value of $10.6 \mathrm{~m}_{\mathrm{ss} \text { tank }}^{3} / \mathrm{MWh}_{\mathrm{demand}}$.

To finalize the modeling process the district network water velocity constrain had to be implemented. ENaQ starting scenario was designed to have a maximum district network water velocity of $2.5 \mathrm{~m} / \mathrm{s}$ which was done by limiting the mass flow of the network pump. Since the network used in this scenario was the same, then the same condition needed to be applied.

The model for simulating the LTDH was composed of the network model (Section 3.1) and the building technologies (or single building model) described in this section. The full validation of the LTDH model can be found in [22] (p. 23).

The single building model is presented in Figure 5.

The operation of the system can be summarized into the following six points:

1. The connection between the heating system and the demands was done via the ondemand storage, which was always supplied by different technologies (solar collector, 
heat pump or electrical resistor) in order to keep the upper tank temperature between $40^{\circ} \mathrm{C}$ and $50^{\circ} \mathrm{C}$. DHW demand at higher temperatures was provided by rising the temperature with an electrical water heater at the outlet.

2. The on-demand storage received energy from the solar collectors if they reached a temperature of $50{ }^{\circ} \mathrm{C}$. If this was not the case, the heat pump supplied energy at $45.5^{\circ} \mathrm{C}$ using the buffer storage as the source side. With a match flow pump, the heat pump returned the temperature at $4{ }^{\circ} \mathrm{C}$ to the buffer storage. If the temperature inside the on-demand storage was too low, an electrical resistor inside the on-demand storage supplies heat until the temperature requirements were fulfilled.

3. The solar collectors worked in two different modes: (i) if the outlet temperature reached $50{ }^{\circ} \mathrm{C}$, it supplied the energy directly to the on-demand storage; (ii) if the collector gained energy but it was not enough to reach $50^{\circ} \mathrm{C}$, then it supplied energy to the buffer storage by adjusting the mass flow to raise the inlet temperature by $10^{\circ} \mathrm{C}$.

4. The buffer storage was the connection point between the district network and the building technologies. In winter it acted as a source for the heat pump by taking energy from the network or the collector when possible. In summer it gave energy to the network which was stored to be used in the winter period and also to stop the overheating of the building system. In case the bottom part of the storage reached $4{ }^{\circ} \mathrm{C}$, the building was disconnected from the network. This led to a cooling of the on-demand storage and consequently the activation of the electrical water heater.

5. The connection point between the single building model and the district network occurred via the scaling factors. These factors increased or decreased the mass flow which went to the network or came from it respectively according to the share of total demand that the single building represented with respect to the district.

6. Concerning the solar collector area (aperture) the design value is $0.061 \mathrm{~m}_{\text {collector }}^{2} / \mathrm{m}_{\text {living area }}^{2}$ The two building storage tanks are sized according to the collector area with values of $59 \mathrm{~L} / \mathrm{m}_{\text {collector }}^{2}$ for the on-demand storage and $118 \mathrm{~L} / \mathrm{m}_{\text {collector }}^{2}$ for the buffer one.

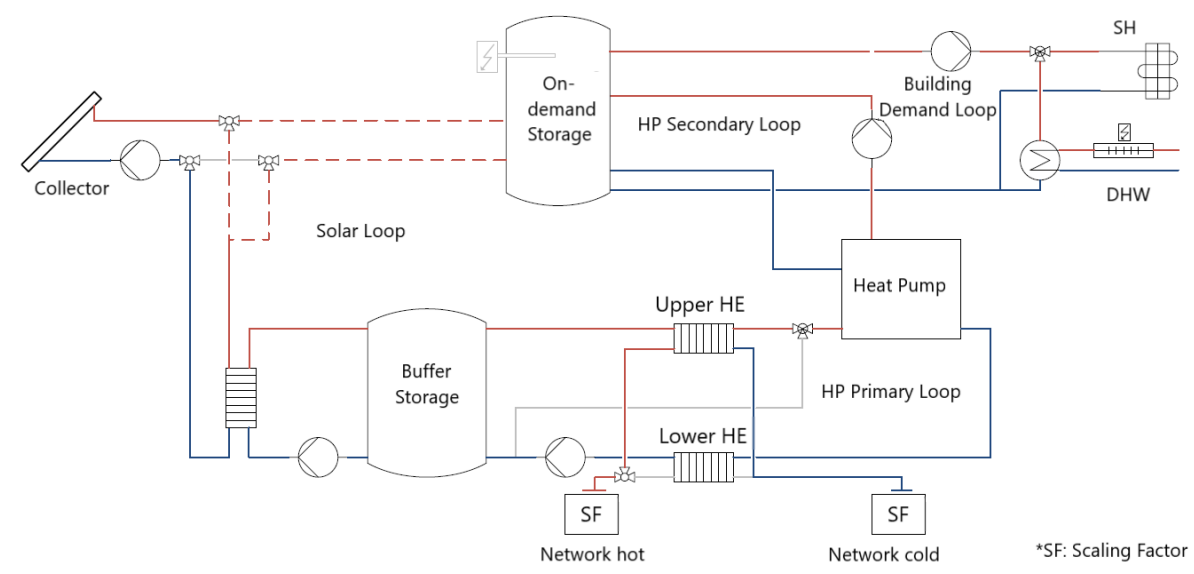

Figure 5. Single building model in the Carnot Toolbox (Figure translated from [21] (p. 19)).

\subsection{Key Performance Indicators}

For comparing both scenarios key performance indicators (from now on KPI) were used. For a meaningful comparison, the following five indicators were selected

1. Share of renewable energy sources (\%): This indicator showed how much energy with respect to the covered demand came from renewable sources. For this study, electricity from the public electricity grid came with a renewable energy share of $35 \%$.

2. Share of electricity used in the system (\%): This indicator showed how much energy with respect to the covered demand, came from electricity. Electricity was used in heat pumps or electric water heaters.

3. Energy taken from the district network (\%): This indicator shows how much energy with respect to the covered demand, is taken from the district network. 
4. Transport losses (\%): This indicator showed how much energy, from the whole energy produced, was lost. Here it is important to mention the difference between supplied energy and transported energy. The first one was the energy that only went from the $\mathrm{CHP} /$ seasonal storage tank to the system while the transported energy was the energy sent from or to the CHP/seasonal storage. In a system with a centralized supply, the supplied energy coincided with the transported energy. However in a system with a seasonal storage the transported energy was always bigger than the supplied since there was energy sent to the seasonal storage and energy taken from it.

5. GHG emissions ( $\left.\mathrm{tCO}_{2} \mathrm{eq}\right)$ : This indicator showed the emissions that the district heating system produced. For this study, emissions for natural gas were considered as $200 \mathrm{~g} / \mathrm{kWh}$ [23] (p. 41) and for the electrical grid $401 \mathrm{~g} / \mathrm{kWh}$ [24].

Economic Comparison between ENaQ Starting (HTDH) and Retrofitted (LTDH) Scenario

After studying the technical district heating system transformation, an economic comparison took place. The tool used to compare these two scenarios was the levelized cost of heat (LCOH) which is described in Equation (5).

$$
L C O H=\frac{\sum_{t=1}^{n} \frac{I_{t}+M_{t}+F_{t}}{(1+r)^{t}}}{\sum_{t=0}^{n} \frac{H_{t}}{(1+r)^{t}}}
$$

This equation calculates from one side, the sum of the project costs divided into investment $I_{t}$, maintenance $M_{t}$ and fuel $F_{t}$ (gas or electricity from the grid) for every year $t$ with a project lifetime of $n$ which in this case was 20 years [25]. On the other hand the heat generated $H_{t}$ is summed over the project life time. With a discount rate of $r$ which in this case is 0.05 , the costs are divided by the heat generated to obtain the cost of generate each kWh of thermal energy.

For this comparison the district network costs (installation and maintenance) were not included since the network was the same for both systems. However the district network pumping costs (electricity) were included because they were not the same. The revenues of selling the electricity produced by the CHP in the HTDH scenario are discounted from fuel or maintenance expenses.

Table 2 shows the electricity and natural gas prices for performing the economic analysis. The carbon tax applied in Germany from 2021 is also presented [26], which was applied only to natural gas and not to electricity since the first one is a direct emission source and electricity is an indirect emission source. Because of that, and the volatility that emissions have in the electrical grid where the carbon footprint changed from hour to hour depending on where electricity came from, it was decided to not apply the tax to electricity and assumed that it already came with the electricity price.

Table 2. Electricity, natural gas and carbon tax prices used in this study.

\begin{tabular}{cc}
\hline Item & Value \\
\hline Natural gas price for CHP & $2.5 \mathrm{ct} / \mathrm{kWh}$ \\
Natural gas price for gas boiler & $3.05 \mathrm{ct} / \mathrm{kWh}$ \\
Electricity purchase price & $21.0 \mathrm{ct} / \mathrm{kWh}$ \\
Electricity sale price & $13.0 \mathrm{ct} / \mathrm{kWh}$ \\
Carbon tax & $€ 25 / \mathrm{tCO}_{2} \mathrm{eq}$ \\
\hline
\end{tabular}

Table 3 shows the investment cost and depreciation period [25] for the technologies proposed in this study. Photovoltaic thermal collectors (PVT) and a seasonal borehole thermal storage (BTES) were also studied as possible options since they could be more economically competitive than solar collectors or pit thermal energy storage (PTES) respectively. 
Table 3. Investment cost and depreciation period for different heating technologies.

\begin{tabular}{ccc}
\hline Technology & Investment Cost $\mathbf{k} € \mathbf{)}$ & Depreciation Period (Years) \\
\hline CHP & 125.0 & 10 \\
Gas boiler & 45.0 & 20 \\
CHP storage & 6.2 & 25 \\
Solar collectors & 221.4 & 20 \\
Heat pumps & 90.0 & 20 \\
Decentralized storage tanks & 84.0 & 25 \\
Heat exchangers & 10.5 & 20 \\
PVT & 311.3 & 30 \\
Inverters & 14.0 & 10 \\
PTES & 867.7 & 25 \\
BTES & 309.9 & 50 \\
\hline
\end{tabular}

For technologies with a depreciation period lower than 20 years, the investment costs were considered again. For those ones where depreciation period was higher than 20 years, their residual values was calculated and added as an income at the end of the project lifetime.

\subsection{Sensitivity Analysis of ENaQ Retrofitted Scenario (LTDH)}

Performing $\mathrm{ENaQ}$ district heating system transformation requires the implementation of several technologies in each building: three heat sources, two storage tanks, three heat exchangers apart from pipes connections and valves. Under this point of view there were three main technology constraints which may have restricted the district heating system transformation because of space constraints. These constraints were the size of solar collector area, the size of seasonal storage tank and the decentralized storage tanks. These were also identified in the literature as the most relevant parameters influencing the performance of the LTDH systems $[7,8]$.

In the present work a sensitivity analysis was carried out to see how these technology constrains could restrict the transformation and influence the system performance. They were divided in two groups: (i) on one hand the size the solar collector field and the seasonal storage tank were varied, since there was a strong relation between these two technologies; (ii) on the other the possibility of having only one decentralized storage on each building instead of two was studied.

\subsubsection{ENaQ Retrofitted with Different Solar Collector Area and Seasonal Storage Tank Volume}

For this sub sensitivity analysis, different scenarios were simulated when either the solar collector area or the seasonal storage tank volume were bigger or smaller as the reference case $(\mathrm{ENaQ}$ retrofitted scenario).

\subsubsection{ENaQ Retrofitted with Only One Decentralized Storage}

In this sub sensitivity analysis one of the two decentralized storage tanks must be removed on each building. Removing the on-demand storage was not possible because there should always be the option of having hot water available if necessary. However it was worth asking how the system performed without the buffer storage. Therefore it was necessary to reconfigure the heat pump primary loop since now this loop was directly connected with the solar loop. As Figure 6 shows, there was a decoupling between the heat pump primary loop and the connection to the district network by adding an extra heat exchanger. With this configuration, and knowing that the inlet temperature of the heat pump was limited to a maximum of $25^{\circ} \mathrm{C}$, there always had to be a discharging process from the building to the seasonal storage when the outlet temperature of the solar collector surpassed $25^{\circ} \mathrm{C}$. 


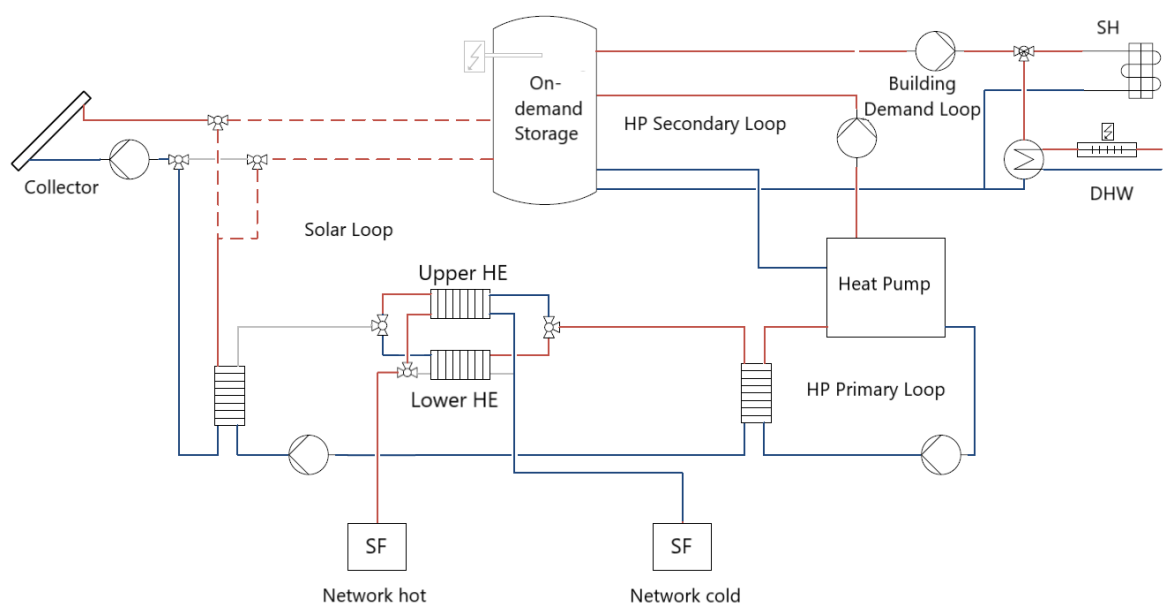

Figure 6. Single building model with one decentralized storage (Figure modified from [21]).

\section{Results and Discussion}

Both scenarios, ENaQ starting and retrofitted were simulated for 1 year with an hourly time step. Then the sensitivity analysis was carried out and finally the economic comparison. Technical results are shown first followed by the economic ones.

\subsection{Technical Comparison between ENaQ Starting (HTDH) and Retrofitted (LTDH) Scenario}

The first comparison between both scenarios involved the temperature of the district heating system. Figure 7 shows the temperature over 1 year for both systems where the red color represents supply and blue return temperatures. Temperatures are also presented as hourly and $24 \mathrm{~h}$ mean values since the hourly values were influenced by the scaling up factor. The reason of this influence lay in the single building model used in the Carnot Toolbox, which meant that all the heat transfer processes between the buildings and the district network happened at the same time and point: where the scaling factor was placed. In reality these processes happened separately in each connection between building and network making the temperature levels much smoother. Because of this, from now onwards the $24 \mathrm{~h}$ mean parameter was used to compare both systems.

$\mathrm{ENaQ}$ starting scenario had almost constant supply and return temperatures of $75^{\circ} \mathrm{C}$ and $35^{\circ} \mathrm{C}$ throughout the year. This is explained by the CHP control strategy which turned on when the centralized storage temperature fell until $70{ }^{\circ} \mathrm{C}$ and fed it with water at $80^{\circ} \mathrm{C}$. This $10^{\circ} \mathrm{C}$ gap could be observed in the hourly values in winter while in summer because of lack of SH demand the return temperature adjusted to the domestic cold water $15^{\circ} \mathrm{C}$ ) thus reducing its value. Concerning the return temperature, the reason of having a constant $24 \mathrm{~h}$ mean value lay on the mass flow strategy designed for this HTDH model. The mass flow in the district network was adjusted to have a temperature difference of $40^{\circ} \mathrm{C}$ between supply and return, and since the supply temperature was constant, then return temperature must also have been.

On the other hand, the temperature behavior in $\mathrm{ENaQ}$ retrofitted scenario was dynamic throughout the year. Supply temperature had a minimum value of $7^{\circ} \mathrm{C}$ in March which began to rise until it reached a maximum of $48^{\circ} \mathrm{C}$ in September. This temperature increase was due to the solar collector gains happening in each building which were transported through the network to the seasonal storage. After 1 month with a constant value of $40^{\circ} \mathrm{C}$ where each building could meet its demands without taking or giving energy to the seasonal storage, in November the temperature level started to fall until it returned to the minimum in March. This happened because the buildings were taking energy from the seasonal storage since they could not meet their heat demands by themselves. Return temperature had a similar trend of supply explained by the same strategy mentioned above. The maximum value reached was $40^{\circ} \mathrm{C}$ in October, which started to fall until reaching its 
minimum of $1{ }^{\circ} \mathrm{C}$ in January. The most frequent minimum value for the return pipe was $4{ }^{\circ} \mathrm{C}$, being maintained until the end of March when it started to rise again.

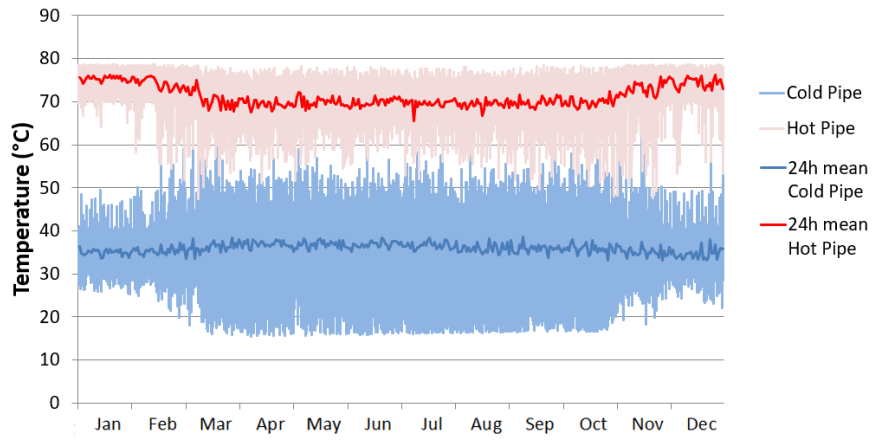

(a) ENaQ starting scenario

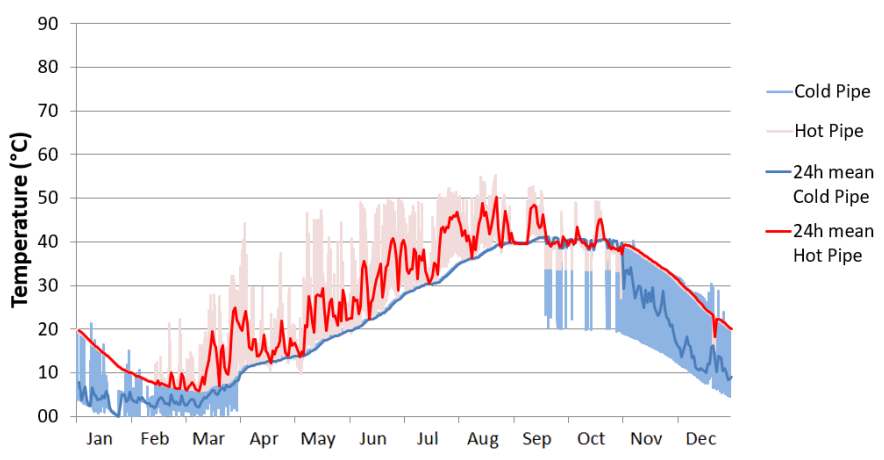

(b) ENaQ retrofitted scenario

Figure 7. Hourly and daily district network temperature in ENaQ.

When comparing these two temperature levels, there were two main differences to highlight. In the first place, the different temperature levels in each system and secondly that the difference $T_{\text {supply }}-T_{\text {return }}$ was much less in ENaQ retrofitted than starting scenario. Figure 8 helps to explain these differences, where the monthly transported energy and volume through the district network for both scenarios is shown.

The transported energy through the network explained the different temperature levels of both systems. In the $\mathrm{ENaQ}$ starting scenario the transport of most of the energy happens in winter, when SH was higher, reaching a peak of $143 \mathrm{MWh}$ in January. In summer there was only DHW demand and it maintained a value around $20 \mathrm{MWh}$. On the other hand, the ENaQ retrofitted scenario had two peaks, one in winter reaching a peak of $81 \mathrm{MWh}$ when buildings were taking energy from the seasonal storage and another one in summer when buildings were giving energy. In October when each building was able to meet its own demand, the transported energy reached a minimum of $6 \mathrm{MWh}$. Thus the role played by the district network in each scenario was totally different which led to the different temperature levels: for the ENaQ starting scenario it was a means of energy transport from the centralized source to the decentralized demands while in ENaQ retrofitted it was a connection between the decentralized energy sources and a centralized seasonal storage.

Observing the low difference $T_{\text {supply }}-T_{\text {return }}$ for $\mathrm{ENaQ}$ retrofitted scenario, and knowing that the specific heat of the water was a constant, the only way to have such an energy transport was by an increase of the transported volume of water. As can be seen in the monthly transported volume, ENaQ starting scenario followed the trend of the energy demand, thus maintaining a constant $T_{\text {supply }}-T_{\text {return }}$ all the year long. ENaQ retrofitted scenario maintained a higher and more constant transport volume. This was only possible due to decentralized storage tanks placed on each building which allowed a water and 
therefore energy transport when was not required and buffer peak demands making the energy transport much smoother. Moreover decentralized storage tanks allowed storing the decentralized generated heat in each building for short periods of time (hour scale). It is important to remark that this high transported volume always maintained the maximum water velocity constraint for which the district network was originally designed. In other words, the $\mathrm{ENaQ}$ starting scenario had few peaks where the maximum water velocity was reached while $\mathrm{ENaQ}$ retrofitted scenario operated constantly at values close to this threshold and with that, was able to transport more water through the district network.

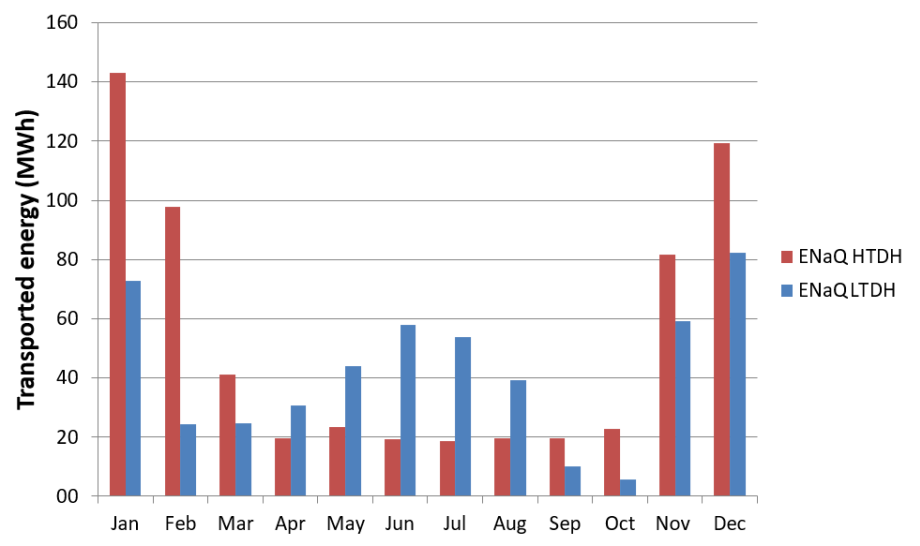

(a) Transported energy

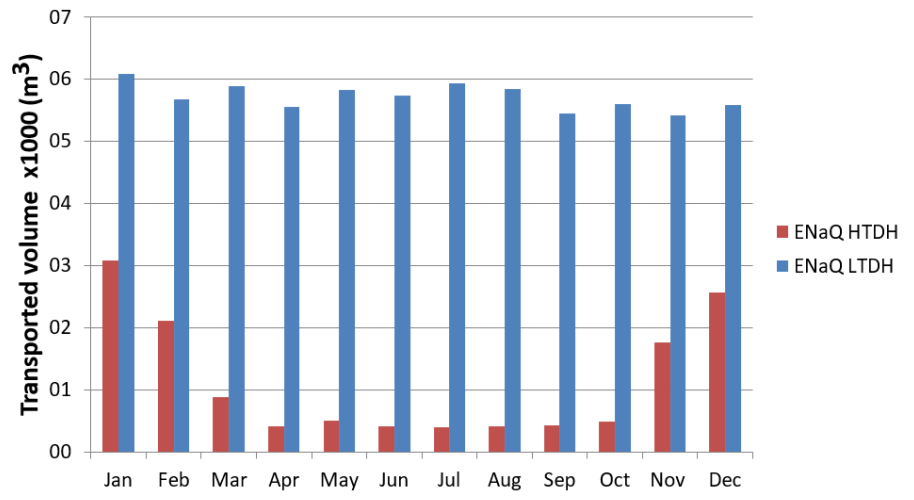

(b) Transported volume

Figure 8. Monthly energy and transport volume trough the district network for ENaQ.

Due to the possibility of reducing the $T_{\text {supply }}-T_{\text {return }}$ and the role that the district network took in one and the other scenario, this transformation was not only about replacing non renewable energy sources by renewable ones but also about changing the district heating system concept.

Continuing with the district heating system comparison Table 4 shows the five KPI for both scenarios.

Table 4. KPI comparison between ENaQ starting and retrofitted scenario.

\begin{tabular}{ccc}
\hline KPI & ENaQ Starting Scenario & ENaQ Retrofitted Scenario \\
\hline Share of renewable energy sources (\%) & 0.3 & 84.0 \\
Share of electricity used in the system (\%) & 0.9 & 24.6 \\
Energy taken from the district network $(\%)$ & 98.9 & 41.1 \\
Transport losses (\%) & 8.3 & 3.4 \\
GHG emissions (tCO $\left.\mathrm{tC}_{2} \mathrm{eq}\right)$ & 135.0 & 57.3 \\
\hline
\end{tabular}


The ENaQ starting scenario operated almost without renewable energy sources or electricity. This is explained by the CHP based design which operated with natural gas. The small amount of renewable came from the electricity used at the electric water heater placed at the DHW for peak loads. Moreover, the CHP was centralized and also the only heat generation source, therefore practically all the energy used was taken from the network reaching $98.9 \%$ of the energy coming from it. With this and the high network temperatures provided by the CHP, transport losses represented $8.3 \%$ of the generated energy which meant 52.7 MWh. The high amount of GHG emissions came mainly from the natural gas used.

The high amount of renewable energy sources used in $\mathrm{ENaQ}$ retrofitted scenario was caused by the replacement of the CHP with solar collectors (a total renewable energy source) and heat pumps (a partial renewable energy source). The electrification of the supply system increased to almost one quarter of the total energy due to the inclusion of heat pumps. If $41.1 \%$ of the energy was taken from the network, it meant that $58.9 \%$ of the demand was met at the same time and place where it was produced. The reason of that was the decentralization of the heat sources in the system. A reduction of $59 \%$ of transport losses occurred mainly but not only because a reduction of the network temperature. The second reason for achieving this reduction was because there was less energy transported through the network than in the $\mathrm{ENaQ}$ starting scenario. The $\mathrm{ENaQ}$ retrofitted scenario transported 238.7 MWh from the seasonal storage to the buildings and 265.5 MWh from the buildings to the storage, making 504.2 MWh in total, while the ENaQ starting scenario transported 626.2 MWh from the CHP to the buildings. Finally, when looking at the GHG emissions, a reduction of $57.6 \%$ was achieved because despite the fact that the share of renewable energy sources increased from $0.3 \%$ to $84 \%$, the electrification of the system increased too, which had higher emission rates than the natural gas.

After analyzing in detail both $\mathrm{ENaQ}$ starting and retrofitted scenario it can be said that the improvement of the retrofitted scenario was considerable. An increase of renewable share from $0.3 \%$ to $84.0 \%$ of the covered demand, reduction of transport losses from $8.3 \%$ to $3.4 \%$ of the generated energy or reduction of GHG emissions of $57.6 \%$ support the previous statement and under these KPI makes this district transformation worthwhile.

The last point to address in this section is how close $\mathrm{ENaQ}$ retrofitted scenario to $\mathrm{ENaQ}$ aiming was. To do that $\mathrm{ENaQ}$ retrofitted was compared with the LTDH reference scenario developed at the beginning of this study and which was based in the TUM study [21]. This means that the district heating system was different than $\mathrm{ENaQ}$ and therefore from all five KPI, neither transport losses can be compared, since the network topology was different, nor the GHG emissions, since the demands were different too. To cope with that problem, these KPI were normalized with the equivalent length $L_{e q}$ and the total demand as Table 5 shows.

Table 5. KPI modified to compare ENaQ retrofitted and LTDH reference scenario.

\begin{tabular}{ccc}
\hline KPI & ENaQ Retrofitted Scenario & LTDH Reference Scenario \\
\hline Share of renewable energy sources (\%) & 84.0 & 83.0 \\
Share of electricity used in the system (\%) & 24.6 & 26.1 \\
Energy taken from the district network (\%) & 41.1 & 35.6 \\
Transport losses (MWh/m Leq) & 0.6 & 0.8 \\
GHG emissions (kg CO 2 eq/MWh demand) & 98.8 & 104.6 \\
\hline
\end{tabular}

The first three indicators had a difference of only $3.1 \%$ in average while for transport losses and GHG emissions there was a slight increase on the LTDH reference scenario. The reason why $\mathrm{ENaQ}$ retrofitted seemed to be better than $\mathrm{ENaQ}$ reference lies in the weather data used on each model. While $\mathrm{ENaQ}$ retrofitted used Oldenburg data from year 2018, LTDH reference scenario used Stötten (Bavaria, Germany) data from years 1988 until 2007. Stötten data were selected for the reference scenario since in the Carnot Toolbox is the closest city to Munich where the TUM model [21] was performed [22] (p. 34). This place and more important year difference led to higher direct radiation in Oldenburg, which led 
to an increase the share of renewable energy sources as well as energy taken from network and consequently decreased the electrification, GHG emissions and transport losses.

Knowing that the LTDH reference scenario in this case corresponded to the ENaQ aiming scenario, the above means that the question established in the introduction has an answer: $\mathrm{ENaQ}$ starting scenario can be retrofitted until it became $\mathrm{ENaQ}$ aiming scenario. There were three key points that allowed this transformation to happen. First, having decentralized sources reduced the energy required from the district network. Second, having decentralized storage tanks allowed higher and more constant transported volume through the network. Finally, having a heat pump on each building right before the outlet to the network allowed a reduction of the return temperature to lower levels than the domestic cold water and consequently a reduction of the supply temperature. These mechanism maximized the difference $T_{\text {supply }}-T_{\text {return }}$ but in temperature levels around $4{ }^{\circ} \mathrm{C}$ and $40^{\circ} \mathrm{C}$ which meant having a low temperature district heating system. These three key points together allowed us to comply with the water velocity constrain even when the difference $T_{\text {supply }}-T_{\text {return }}$ reduces.

\subsection{Sensitivity Analysis of $E N a Q$ Retrofitted Scenario (LTDH)}

In this subsection, results are presented for cases when the transformation could not be $100 \%$ performed. First results with different values of collector field and seasonal storage tank are presented. Then results are shown for cases when the buffer storage could not be placed.

\subsubsection{ENaQ Retrofitted with Different Solar Collector Area and Seasonal Storage Tank Volume}

Here scenarios were simulated with different solar collector area or seasonal storage. For each scenario the five KPI were calculated and Figure 9 shows as an example the GHG emissions indicator. The other four indicators are presented in Appendix C. The size of the variables ranges from $40 \%(0.4)$ to $140 \%$ (1.4) of the reference which was the $\mathrm{ENaQ}$ retrofitted scenario.

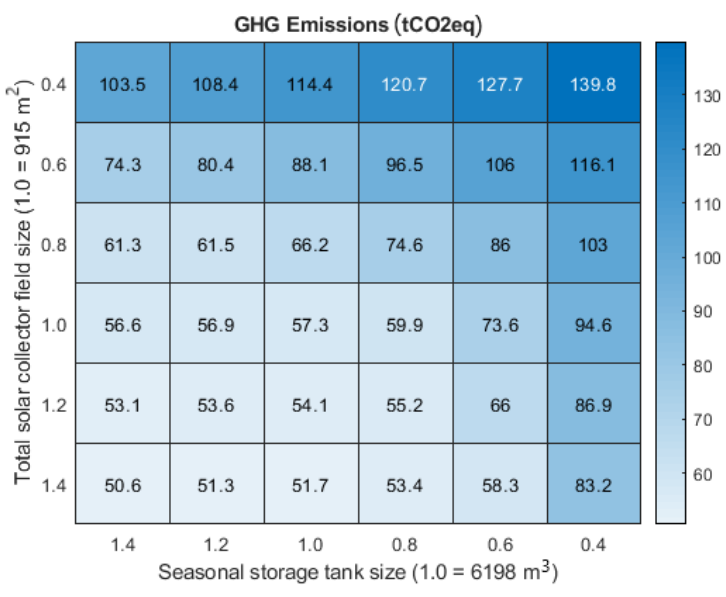

Figure 9. GHG emissions for different sizes of solar collector field and seasonal storage tank.

The first point to mention is that as the size of the solar collector field or the seasonal storage grew, the emissions decreased. To explain that is necessary to know that the GHG emissions came only from electricity which was used either by the heat pumps or the electrical water heaters. Therefore if the solar collector area increased, then solar energy yield increased, leading to a reduction in the energy required from the heat pump and consequently the GHG emissions. Concerning the seasonal storage, a bigger volume led to an increase of its heat capacity, reducing the temperature level for the same amount of stored energy and subsequently transport losses were reduced. In consequence, the solar fraction increased leading to a reduction of the electricity demands for the heaters and heat pump and to a decrease in the GHG emissions. 
The second point to mention is that the influence of any of these two variables was not linear. The bigger the solar collector field iswas the lower the influence of the seasonal storage in the GHG emissions: when the collector size was 1.4 times bigger than the reference case, a reduction of the seasonal storage size from $140 \%$ to $40 \%$ of the reference case increased the emissions by $64.4 \%$ but when the collector size was $40 \%$ of the reference case, the same seasonal storage variation increased the emissions by $35.1 \%$. The same principle applies when fixing the seasonal storage tank volume. For the solar collector this is explained by the minimum energy required to turn on the match flow pump: with smaller areas, this threshold was more difficult to reach in order to turn it on. Due to this, on some days where in the base case the collector pump was on, now it was off. Similar to the first point, less use of solar collector meant more use of heat pump or water heater and more emissions. For the seasonal storage it had to do with the temperature difference between the soil and the district network: with smaller seasonal tank sizes, the district network temperature increased more, making losses higher. When the seasonal storage was big enough (e.g., reference case) this temperature difference became increasingly irrelevant to the point where it could no longer be reduced. This energy loss came only from the solar collector, which meant that heat pump or water resistor needed to cover this deficit, leading to increased emissions.

These two points meant that bigger sizes of solar collector fields or seasonal storage tanks, allowed them to increase the use of solar energy, and therefore reduce the energy that needed to be covered by electricity. However, the electricity share indicator, and consequently the emissions indicator, could never be equal to zero since a key component of the system, the heat pumps, made use of electricity. The previous meant that the electricity used on the system could be divided into two components: the one which went to the heat pumps, and the one which went to the electric water heaters. The first component could not be removed while the second one can be, if the variable sizes were big enough. It is important to remark that emissions were a fixed rate from the grid electricity $\left(401 \mathrm{~g} / \mathrm{kWh}_{\mathrm{el}}\right)$ and in the future this value will decline making ENaQ retrofitted to emit less and less.

Under the heat maps generated for each KPI, it was possible to generate guidelines for when the transformation could not be 100\% performed. It is important to remark that each indicator had its own behavior which meant that for following a specific indicator it was necessary to look only at its specific heat map. Said that the following guidelines were developed taking under consideration the five KPI:

- Guideline for when the seasonal storage tank was limited: if the size of it was $80 \%$ of the nominal value, the transformation was worth it presenting small declines on its performance. If the size was $60 \%$ of the nominal value, the problem could be solved by increasing the size of the solar collector field at least $20 \%$ of its nominal value. If the tank size was $40 \%$ of its nominal value or lower, it is likely that the transformation was not feasible since there was a fall of $44.8 \%$ of the system performance compared with the reference case.

- Guideline for when the solar collector field was limited: if the field size was $80 \%$ of the nominal value, again there were no big problems for performing the transformation. If the field size was $60 \%$ of the nominal value, the transformation may not be feasible, even when the size of the seasonal storage tank increased. If the solar collector field size was $40 \%$ of the nominal value, it is likely that the transformation was not feasible since there was a fall of $38.0 \%$ of the system performance ( $55 \%$ without transport losses indicator) compared with the reference case.

- Guideline for when both the seasonal storage tank and the solar collector field were limited: if both sizes were $80 \%$ of their nominal values, the transformation was worth doing presenting small declines on its performance. If both values were $60 \%$ of the nominal values, the transformation may not have been feasible. If both values were $40 \%$ of their nominal values, then the transformation was definitely not worth it since the emissions were higher than the HTDH scenario. 


\subsubsection{ENaQ Retrofitted with Only One Decentralized Storage}

Table 6 shows the five KPI for ENaQ retrofitted with one and two decentralized storage tanks.

Table 6. KPI comparison between $\mathrm{ENaQ}$ retrofitted with one and two decentralized storage tanks.

\begin{tabular}{ccc}
\hline KPI & Two Decentralized Tanks & One Decentralized Tank \\
\hline Share of renewable energy sources (\%) & 84.0 & 78.5 \\
Share of electricity used in the system (\%) & 24.6 & 33.2 \\
Energy taken from the district network (\%) & 41.1 & 35.0 \\
Transport losses (\%) & 3.4 & 1.8 \\
GHG emissions ( $\left.\mathrm{tCO}_{2} \mathrm{eq}\right)$ & 57.3 & 77.5 \\
\hline
\end{tabular}

Starting by the share of renewable energy sources, scenario with one decentralized storage had a slight decrease from $84 \%$ to $78.5 \%$. This was due to less energy coming from solar collectors which was covered by electricity. This less energy from collectors occurred when they reached a temperature above $25^{\circ} \mathrm{C}$ and the heat pump was on. In that situation, solar collectors stopped gaining energy and started to discharge the energy gained until this point to the seasonal storage through the district network which had a limited capacity of transporting energy and as a result 32.1 MWh of solar heat were dumped in comparison when there was a buffer storage. The increase of electricity used in the system had two reasons. On one side, in the same situation described above, the lower heat supplied by the heat pump was covered by the electric water heater placed inside the on-demand storage which needed more electricity for providing the same amount of heat. The second reason involved the heat pump. In the two storage system, the buffer storage was the inlet to the heat pump. This buffer storage was hot at the top and cold at the bottom. Solar gains kept the top of the buffer storage tank around $20^{\circ} \mathrm{C}$ in winter, allowing an efficient operation of the heat pump. The temperature at the top of the buffer storage only started to decrease in mid-February after the heat pump worked continuously throughout January and even there, some solar gains increased the temperature for some hours. Without the buffer storage, the inlet temperature for the heat pump due to its direct connection to the seasonal storage. Moreover, solar gains had to be used in the very same time they were produced, because there was not storage option for them. This decrease in the inlet temperature of the heat pump led to a reduction in its COP, increasing the electricity required and the resulting GHG emissions.

The energy taken from network decreased from $41.1 \%$ to $35 \%$ due to the inlet temperature limitation in the heat pump and the solar energy dumped as a result. The reduction in the energy transported in the network as well as the lower network temperatures led to a strong of the network heat losses from 20.7 MWh to 10.8 MWh. As said before the cut off in winter when the collector field reached $25^{\circ} \mathrm{C}$ reduced the energy sent to the seasonal storage and therefore the energy taken from it. Finally because of less energy transported in the district network along with the impediment to overcome temperatures higher than $25{ }^{\circ} \mathrm{C}$ in most part of the year, led to a strong losses reduction from $20.7 \mathrm{MWh}$ to $10.8 \mathrm{MWh}$.

From a general perspective the system performance with only one decentralized storage was moderately affected: when all five KPI were observed, taking into account that the transport losses indicator had a performance increase of $47.1 \%$, the one storage system losses had $8.8 \%$ performance in comparison with the two storage system. When the transport losses indicator was taken out, the system had a drop in performance of $22.8 \%$. Nevertheless the mayor challenge with this system configuration was the daily change of the mass flow direction in the district network in winter. Figure 10 shows the control signal for the flow direction in the district network for the first week of February in an hourly time step. A flow direction signal of 1, meant the building was taking energy from the seasonal storage while a flow direction signal of 0 meant the building was giving energy to the seasonal storage changing the direction of the mass flow. 


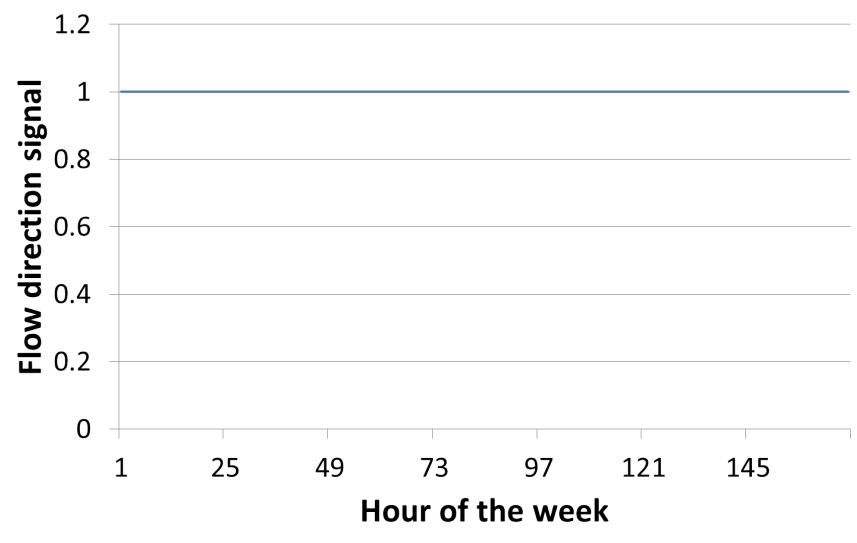

(a) Two decentralized tanks

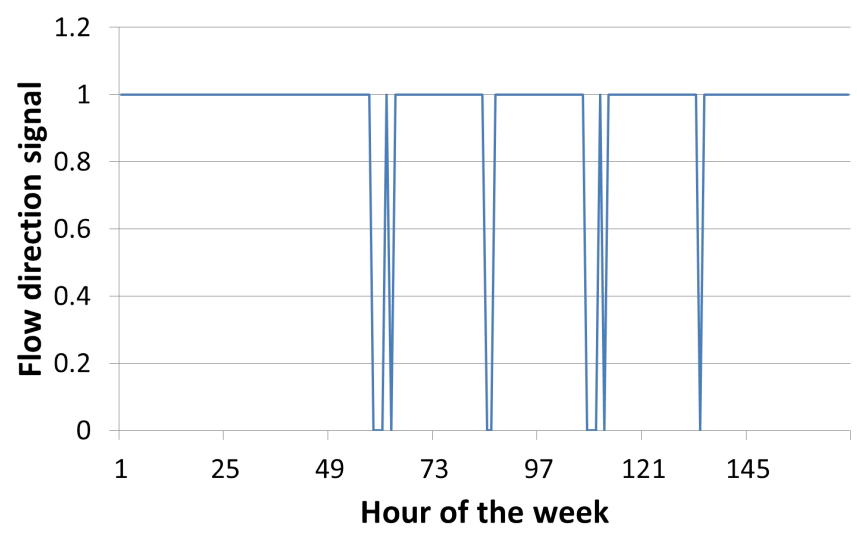

(b) One decentralized tank

Figure 10. Flow direction signal in the district network for ENaQ retrofitted (first week of February).

For the system with two decentralized storage tanks, the signal had a constant value of 1 , which meant that the mass flow had the entire week the same direction: from the seasonal storage to the buildings. On the other hand, in the system with one decentralized storage tank, there were 4 of 7 days where the solar collector field reaches temperatures above $25^{\circ} \mathrm{C}$ and therefore the direction of the mass flow needed to change for 1 or $2 \mathrm{~h}$ until the collector outlet temperature returned to levels below $25^{\circ} \mathrm{C}$. This change of mass flow direction represents a hydraulic challenge that needs to be studied in detail and is the main issue for using one decentralized storage tank.

\subsection{Economic Comparison between ENaQ Starting (HTDH) and Retrofitted (LTDH) Scenario}

Table 7 shows the levelized cost of heat for ENaQ starting and retrofitted scenario. Here it can be observed that the cost of each $\mathrm{kWh}$ was 4.46 times bigger for $\mathrm{ENaQ}$ retrofitted scenario, so with current economic conditions it was hard for an innovative and efficient district heating system to compete with $\mathrm{ENaQ}$ starting scenario (based on centralized $\mathrm{CHP}$ ) under these conditions.

Table 7. Levelized cost of heat for ENaQ starting and ENaQ retrofitted scenario.

\begin{tabular}{cc}
\hline Scenario & LCOH (ct/ $/ \mathbf{k W h})$ \\
\hline ENaQ starting scenario & 5.0 \\
ENaQ retrofitted scenario & 22.3 \\
\hline
\end{tabular}


In order to make ENaQ retrofitted more economically competitive, three main changes were made that reduced its $\mathrm{LCOH}$ and are listed as follows:

1. The seasonal storage from PTES to BTES: the original pit thermal energy storage was replaced by a borehole thermal energy storage. In order to store the same amount of energy a volume of around $13,000 \mathrm{~m}^{3}$ of ground was needed, which could be achieved with deep probes $[27,28]$. This technology not only needed lower investment costs but it also had a longer lifetime.

2. Reduce the seasonal storage to $80 \%$ of its nominal value: the sensitivity analysis performed with different solar collector area and seasonal storage volume showed that the best case, economically speaking, was when the seasonal storage was $80 \%$ of the nominal value and the solar collector area $100 \%$. This was due to a stronger reduction in the investment cost of the seasonal storage while the electricity needed remained around 25\%. When reducing the seasonal storage to lower values, then the electricity demand increased making the solution more expensive.

3. Replace solar collectors for photovoltaic thermal collectors (PVT): when using PVT the heat output of the solar collector decreased but the electricity produced could be used by the heat pumps. Since PVT made use of solar radiation, most of electricity generation occurred in summer when heat pumps did not work. Because of that the electricity consumption of the system decreased only by $15 \%$ but in this scenario the electricity sold in summer decreased the LCOH considerably since the same principle for the CHP electricity generation was applied here too.

With this three main changes, a new scenario was described where the focus was not only on improving the KPI, but also reducing the $\mathrm{LCOH}$ as much as possible. This new scenario was called Economical ENaQ retrofitted and Figure 11 shows the LCOH of it along with the intermediate steps to show the impact that each change had.

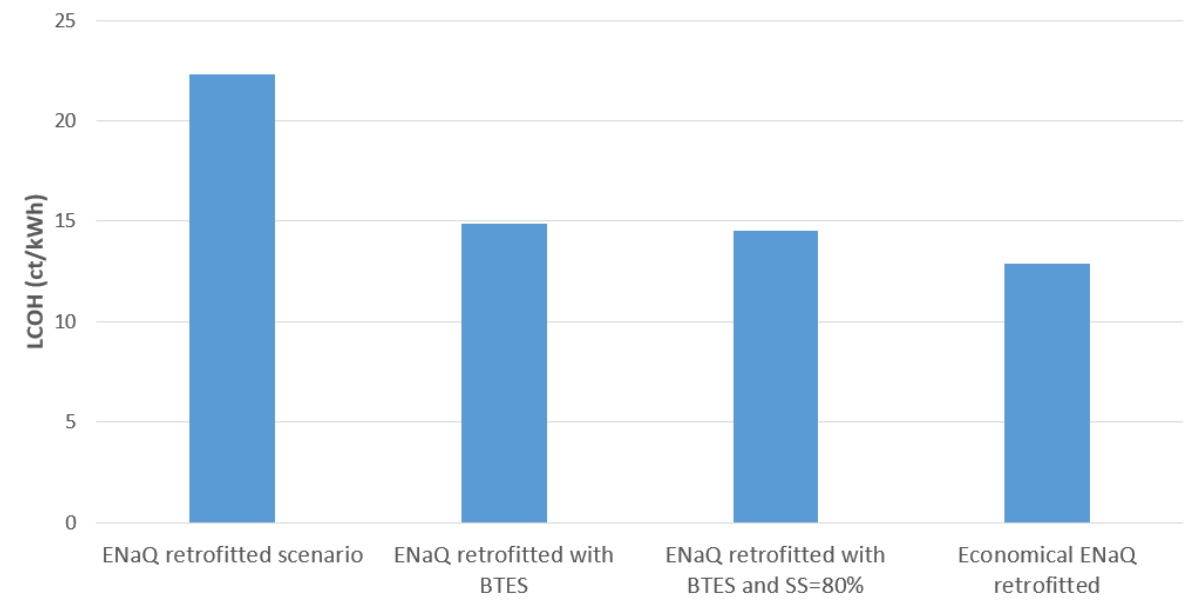

Figure 11. $\mathrm{LCOH}$ for $\mathrm{ENaQ}$ retrofitted and economical $\mathrm{ENaQ}$ retrofitted along with its intermediate steps.

The previous figure shows that replacing the PTES tank with a BTES had the greatest impact on reducing the $\mathrm{LCOH}$, lowering it from 22.3 to $14.9 \mathrm{ct} / \mathrm{kWh}$ which meant a reduction of $33.2 \%$. This happens because the seasonal storage implementation was the largest investment that had to be made to achieve the district heating transformation. Using a seasonal storage of $80 \%$ of the nominal value $\left(4958 \mathrm{~m}^{3}\right.$ of water equivalent) had the least impact on reducing the $\mathrm{LCOH}$, lowering from 14.9 to $14.5 \mathrm{ct} / \mathrm{kWh}$ which means a $1.8 \%$ reduction with respect to $\mathrm{ENaQ}$ retrofitted scenario. Finally, replacing solar collectors by PVT had a moderate impact on the LCOH reduction, lowering it from 14.5 to $12.9 \mathrm{ct} / \mathrm{kWh}$ which meant a $7.2 \%$ reduction with respect to $\mathrm{ENaQ}$ retrofitted scenario.

The idea of having a big centralized heat pump or solar collector field is attractive since the investment and maintenance costs would be much lower, due to economy of scale. Nevertheless this would mean that all the energy came from a centralized heat source 
which would increase the energy transport through the network and therefore it would require bigger pipe diameters (transport the same amount of energy as $\mathrm{ENaQ}$ starting scenario but with lower temperatures). This would force to change the district network, which would again increase the investment costs.

After obtaining the best scenario in economic terms to perform the district heating transformation, Table 8 shows a summary of the levelized cost of heat for ENaQ starting, retrofitted and economical $\mathrm{ENaQ}$ retrofitted scenarios.

Table 8. Levelized cost of heat for $\mathrm{ENaQ}$ starting, retrofitted and economical ENaQ retrofitted scenario.

\begin{tabular}{cc}
\hline Scenario & LCOH (ct/kWh) \\
\hline ENaQ starting scenario & 5.0 \\
ENaQ retrofitted scenario & 22.3 \\
Economical ENaQ retrofitted & 12.9 \\
\hline
\end{tabular}

The values of this table show that even the best technology combination for ENaQ retrofitted had a $\mathrm{LCOH}$ twice as high as $\mathrm{ENaQ}$ starting scenario. This was due to the low natural gas price for big costumers in Oldenburg which meant that currently, the CHP alone generated profits (running at full load for $1 \mathrm{~h}$ cost $€ 4$ of natural gas plus $€ 1.25$ of maintenance plus $€ 0.8$ of carbon tax and generated $€ 5$ of heat plus $€ 7$ of electricity). If the gas prices were the same as for normal citizens in Germany, $5.3 \mathrm{ct} / \mathrm{kWh}$ for multi family houses and $6.0 \mathrm{ct} / \mathrm{kWh}$ for single family houses, then the $\mathrm{LCOH}$ for $\mathrm{ENaQ}$ starting scenario would be $9.2 \mathrm{ct} / \mathrm{kWh}$ and $10.3 \mathrm{ct} / \mathrm{kWh}$ respectively, being on the range of those from the economical $\mathrm{ENaQ}$ retrofitted scenario. Furthermore a natural gas price of $7.7 \mathrm{ct} / \mathrm{kWh}$ would be required for $\mathrm{ENaQ}$ starting and economical $\mathrm{ENaQ}$ retrofitted to have the same $\mathrm{LCOH}$.

This study compared a low cost, fossil fuel and high temperature technology with an expensive, renewable and low temperature technology. The comparison shows that a renewable innovative and efficient district heating system could hardly compete with standard fossil-based high temperature solutions under current economic conditions.

Following the goal to reach carbon neutrality in 30 years, in line-among others-with "Climate Action Plan 2050" the gas used by the CHP must at least come from renewable energy sources, such as power to gas technologies or biogas. This would make the gas price much more expensive than the current one and change the economic viability or the LTDH strongly.

\section{Conclusions}

After presenting and discussing the results obtained in this study, its conclusions can be divided into technical and economic ones.

From the technical side, the first and foremost conclusion concerns the district heating system transformation from high to low temperature. The transformation until the very low temperature system is possible. The three key points that allow this transformation to happen are (i) the use of decentralized heat sources, (ii) the use of decentralized heat storage tanks and (iii) the placement of heat pumps at the outlet of each building. These key points allow to comply with the water velocity constrain even when the difference between supply and return temperature reduces. Moreover, this transformation is not only about replacing fossil fuel technologies by renewable ones but is a transformation of the district heating concept. The district network is no longer a connection between source and demands, but is a connection between buildings and seasonal storage to store the surplus of energy in summer and use it in winter. Guidelines were also developed for when the transformation can not be fully performed due to space constrains. If the seasonal storage is limited, then the transformation is worth until $60 \%$ of the nominal value $\left(10.6 \mathrm{~m}_{\mathrm{sstank}}^{3} / \mathrm{MWh}_{\mathrm{demand}}\right)$ is reached. If the solar collector area is limited, the transformation is worth until $80 \%$ of the nominal value $\left(0.061 \mathrm{~m}_{\text {coll }}^{2} / \mathrm{m}_{\text {livingarea }}^{2}\right)$ is reached. Finally, if there is space for only one decentralized storage on each building, the transformation is worth performing but it is 
necessary to study if it is hydraulically feasible due to changes of the mass flow direction in the district network.

Regarding the economic conclusions, there are three aspects that must be considered to reduce the levelized cost of heat of the transformation. The first, and the one that causes the most impact, is that a borehole thermal energy storage (BTES) is more economic than a pit thermal energy storage (PTES) as seasonal storage technology since the first has a lower investment cost and a longer lifetime. The second consideration is that installing photovoltaic thermal collectors is more economic than installing solar thermal collectors since the first ones reduce a bit the thermal output but produce electricity which can be used by the heat pump or sold to the grid. The last aspect to consider is the size of the seasonal storage which is more economical when it has a size of $80 \%$ of the nominal value since the installation and maintenance costs reduce while the electricity needs remain almost constant compared to the nominal value scenario.

With the current conditions, the transformation is not economically convenient, due to low natural gas prices. Therefore there is a strong need to change these low gas prices. Possible ways for this can be the implementation of stronger carbon taxes (the German Environment Agency (UBA) estimates that the real cost of emitting $1 \mathrm{tCO}_{2} \mathrm{eq}$ is $€ 189$ at year 2021 [29]) or renewable technologies subsidie. Nevertheless, knowing that Germany aims for zero emissions by 2050, a fair economic comparison would include gas from renewable sources such as power to gas technologies or biogas. Under this condition, if the gas price is higher than $7.7 \mathrm{ct} / \mathrm{kWh}$, then a retrofitted scenario would have a cheaper levelized cost of heat, making it a better solution. This shows the importance of creating economic frameworks that promote the implementation of efficient LTDH instead of hindering it if climate goals in the heat sector are to be achieved.

Author Contributions: Conceptualization, methodology: P.D., H.T., P.S., P.K., K.v.M. and C.A.; formal analysis, investigation, validation: P.D. and H.T.; data curation, software, visualization, writing-original draft preparation: P.D.; resources, project administration: P.K.; writing-review and editing: H.T., P.K. and B.H.; supervision: H.T., P.S., P.K and B.H.; funding acquisition: P.K., B.H, K.v.M. and C.A. All authors have read and agreed to the published version of the manuscript.

Funding: This research was funded by the Federal Ministry for Economic Affairs and Energy (BMWi) and the Federal Ministry of Education and Research (BMBF) of Germany in the project $E N a Q$ (project number 03SBE111).

Institutional Review Board Statement: Not applicable.

Informed Consent Statement: Not applicable.

Data Availability Statement: Not applicable.

Acknowledgments: Thanks to Thomas Auer, Isabell Nemeth and Karl Martin Heißler from the Technical University of Munich for providing the data to validate the LTDH models. Secondly, thanks to Lucas Schmeiling for providing facts and prices about heating technologies. Finally thanks to Dietrich Schmidt and Svend Svendsen for your precious feedback on the results.

Conflicts of Interest: The authors declare no conflict of interest.

\section{Abbreviations}

The following abbreviations are used in this manuscript: 


$\begin{array}{ll}\text { Abbreviations } & \\ \text { GHG } & \text { greenhouse gases } \\ \text { SH } & \text { space heating } \\ \text { domestic hot water } & \text { low temperature district heating } \\ \text { LTDH } & \text { high temperature district heating } \\ \text { HTDH } & \text { combined heat and power } \\ \text { CHP } & \text { heat exchanger } \\ \text { HE } & \text { photovoltaic thermal } \\ \text { PVT } & \text { coefficient of performance } \\ \text { COP } & \text { Energetic Neighbourhood Quarter } \\ \text { ENaQ } & \text { Technical University of Munich } \\ \text { TUM } & \text { key performance indicator } \\ \text { KPI } & \text { levelized cost of heat } \\ \text { LCOH } & \text { pit thermal energy storage } \\ \text { PTES } & \text { borehole thermal energy storage } \\ \text { BTES } & \end{array}$

Nomenclature

Variable

$\dot{Q}_{\text {transported }}$

$c_{\mathrm{pw}}$

$\dot{m}_{\mathrm{W}}$

$\mathrm{T}_{\text {supply }}$

$\mathrm{T}_{\text {return }}$

$\mathrm{L}_{\mathrm{eq}}$

$\mathrm{L}_{\mathrm{i}}$

$\dot{m}_{\mathrm{i}}$

$\mathrm{U}_{\mathrm{eq}}$

$\mathrm{U}_{\mathrm{i}}$

$\mathrm{k}$

$\mathrm{r}_{\text {out,i }}$

$\mathrm{r}_{\mathrm{in}, \mathrm{i}}$

$\dot{Q}_{\text {loss }}$

$\Delta \mathrm{T}$

$\mathrm{LCOH}$

$\mathrm{I}_{\mathrm{t}}$

$\mathrm{M}_{\mathrm{t}}$

$\mathrm{F}_{\mathrm{t}}$

$\mathrm{r}$

$\mathrm{n}$

Indexes

\section{Description}

Heat transported through the network

specific water heat capacity

water mass flow

supply temperature

return temperature

equivalent pipe length

pipe length in each segment

Segment mass flow

Equivalent pipe heat transfer coefficient

Segment (i) pipe heat transfer coefficient

Thermal conductivity of the insulation

Segment (i) pipe outer diameter

Segment (i) pipe inner diameter

Thermal losses in the network

Temperature difference between pipe and ambient

Levelized cost of heat

Investment costs per year $(\mathrm{t})$

Maintenance costs per year $(t)$

Fuel costs per year $(t)$

Discount rate

Project lifetime

Years of project life

Network segment
Units

$\mathrm{kW}$

$\mathrm{kJ} \mathrm{kg}^{-1} \mathrm{~K}^{-1}$ $\mathrm{kg} \mathrm{s}^{-1}$

${ }^{\circ} \mathrm{C}$

${ }^{\circ} \mathrm{C}$

$\mathrm{m}$

$\mathrm{m}$

$\mathrm{kg} \mathrm{s}^{-1}$

$\mathrm{W} \mathrm{m} \mathrm{m}^{-1} \mathrm{~K}^{-1}$

$\mathrm{W} \mathrm{m}^{-1} \mathrm{~K}^{-1}$

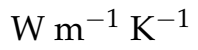

$\mathrm{m}$

$\mathrm{m}$

$\mathrm{kW}$

$\mathrm{K}$

EUR year $^{-1}$

EUR $_{\text {year }}{ }^{-1}$

EUR year $^{-1}$

$-$

Years $\mathrm{t}$ i

Appendix A. Values for Characterizing Storage and Solar Collectors Used in the Models

$\begin{array}{ll}\text { Variable } & \text { Description } \\ v_{0} & \text { Zero loss efficiency } \\ \mathrm{a}_{1} & \text { linear heat loss coefficient } \\ \mathrm{a}_{2} & \text { quadratic heat loss coefficient } \\ \mathrm{c}_{\text {eff }} & \text { effective heat capacity } \\ \dot{m}_{\text {coll }} & \text { design mass flow } \\ \mathrm{A}_{\text {coll }} & \text { aperture area } \\ \mathrm{A}_{\text {gross }} & \text { gross area }\end{array}$

$\begin{array}{ll}\text { Units } & \text { Value } \\ - & 0.820 \\ \mathrm{~W} \mathrm{~m} \mathrm{~m}^{-2} \mathrm{~K}^{-1} & 3.61 \\ \mathrm{~W} \mathrm{~m} \mathrm{~K}^{-2} \mathrm{~K}^{-2} & 0.008 \\ \mathrm{~kJ} \mathrm{~m}^{-2} \mathrm{~K}^{-1} & 10 \\ \mathrm{~kg} \mathrm{~m}^{-2} \mathrm{~s}^{-1} & 0.022 \\ \mathrm{~m}^{2} & 2.56 \\ \mathrm{~m}^{2} & 2.73\end{array}$


Appendix B. Values for Characterizing Storage and Solar Collectors Used in the Models

$\begin{array}{lll} & \text { Reference Case Relation } & \begin{array}{l}\text { Units } \\ \mathrm{m}^{2} \mathrm{~m}_{\text {living area }}^{-2}\end{array} \\ \text { Bolar collector area } & 0.061 & 1 \mathrm{~m}_{\text {coll }}^{-2} \\ \text { On-demand storage size } & 59 & 118 \\ \text { Seasonal storage size } & 6198 & \mathrm{~m}^{3}\end{array}$

Appendix C. KPI for Sensitivity Analysis of Different Solar Collector Area and Seasonal Storage Volume

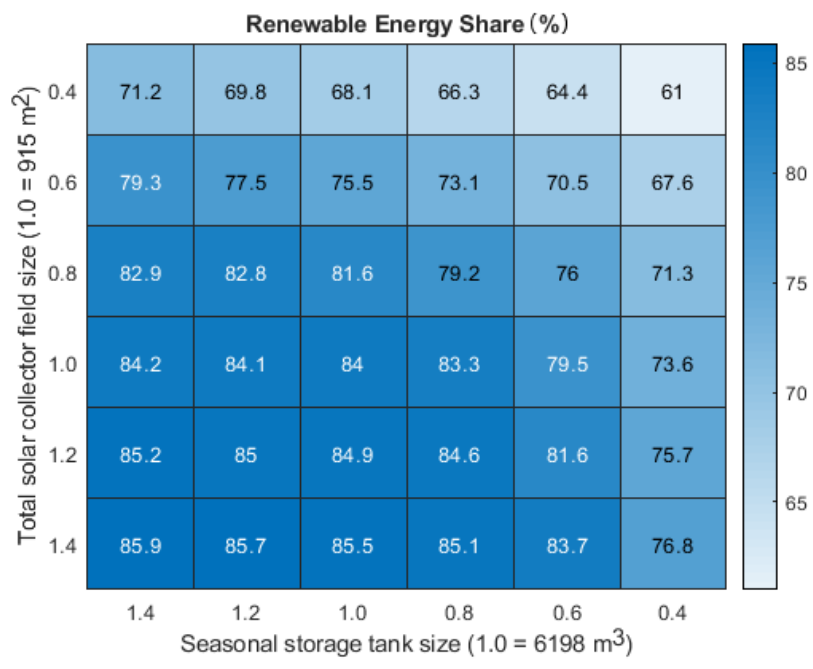

(a) Renewable energy used

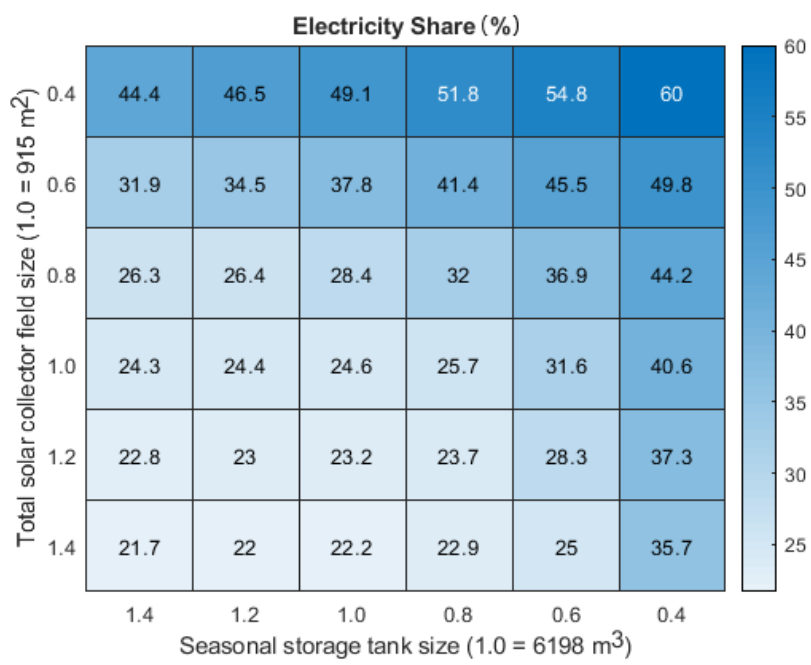

(b) Electricity used

Figure A1. KPI for different sizes of solar collector field and seasonal storage tank. 


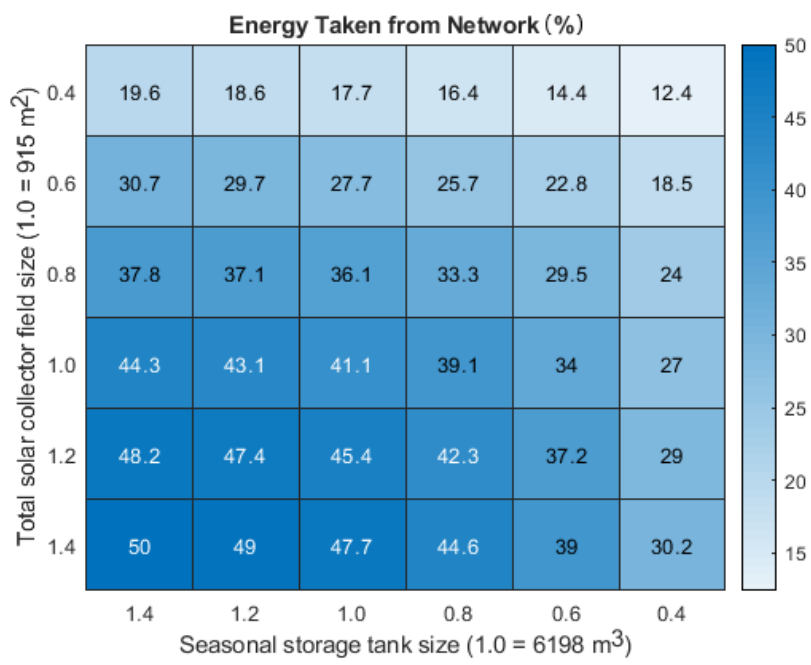

(a) Energy taken from network

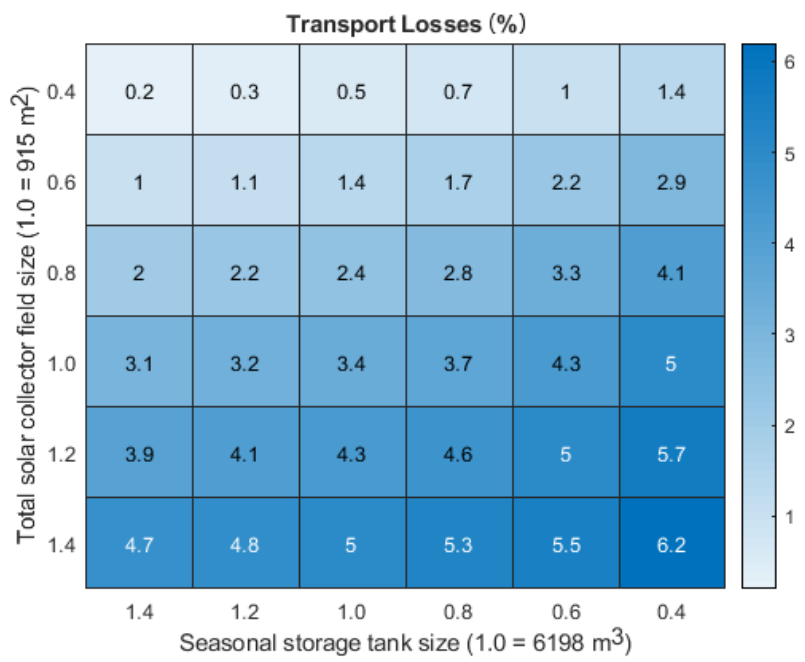

(b) Transport losses

Figure A2. KPI for different sizes of solar collector field and seasonal storage tank.

\section{References}

1. Klima-Allianz Deutschland. Klimaschutzplan 2050 der Deutschen Zivilgesellschaft; Bundesministerium für Umwelt, Naturschutz und nukleare Sicherheit: Berlin, Germany, 2016.

2. $\quad$ Bundesverband der Energie- und Wasserwirtschaft e.V. Entwicklung des Wärmeverbrauchs in Deutschland; Foliensatz zur BDEWPublikation: Berlin, Germany, 2019.

3. Oschatz, B.; Mailach, B. Planung Neuer Wohngebäude nach Energieeinsparverordnung 2009 und Erneuebare-Energien-Wärmegesetz; Bundesministerium für Verkehr, Bau und Stadtentwicklung: Berlin, Germany, 2010.

4. Umweltbundesamt. Eneuebare Energie in Zahlen. 2020. Available online: https://www.umweltbundesamt.de/themen/klimaenergie/erneuerbare-energien/erneuerbare-energien-in-zahlen (accessed on 29 July 2020).

5. Deutsch, M.; Gerhardt, N.; Schumacher, P. Heat Transition 2030-Key Technologies for Reaching the Intermediate and Long-Term Climate Targets in the Building Sector; Agora Energiewende: Berlin, Germany, 2017.

6. Schmidt, D.; Sager, C.; Kallert, A. LowEx Communities-Optimised Performance of Energy Supply Systems with Exergy Principles (Annex 64); Inernational Energy Agency-EBC: Stuttgart, Germany, 2014.

7. Wang, D.; Carmeliet, J.; Orehounig, K. Design and Assessment of District Heating Systems with Solar Thermal Prosumers and Thermal Storage. Energies 2021, 14, 1184. [CrossRef]

8. Hsieh, S.; Omu, A.;Orehounig, K. Comparison of solar thermal systems with storage: From building to neighbourhood scale. Energy Build. 2017, 152, 359-372. ISSN 0378-7788. [CrossRef]

9. Euroheat \& Power. District Energy in Germany. 2019. Available online: https:/ /www.euroheat.org/knowledge-hub/districtenergy-germany/ (accessed on 17 July 2020).

10. Deutsch, M.; Langenhled, A. Wie Werden Wärmenetze Grün? Agora Energiewende: Berlin, Germany, 2019. 
11. Schweikardt, S.; Didycz, M.; Engelsing, F. Sektoruntersuchung Fernwärme; Bundeskertellamt: Bonn, Germany, 2012.

12. Kunz, F.; Kendziorski, M.; Schill, W.P. Electricity, Heat, and Gas Sector Data for Modelling the German System; Deutsches Institut für Wirtschaftsforschung: Berlin, Germany, 2017.

13. Nussbaumer, T.; Thalmann, S. Sensitivity of System Design on Heat Distribution Cost in District Heating (Task 32); International Energy Agency-Bioenergy: Zürich, Switzerland, 2014.

14. ENaQ Project. Das Smart City Living Lab Oldenburg. 2020. Available online: https://www.enaq-fliegerhorst.de/teilprojekte/ (accessed on 17 July 2020).

15. Köfinger, M.; Basciotti, D.; Schmidt, R.R. Reduction of return temperatures in urban district heating systems by the implementation of energy cascades. Energy Procedia 2017, 116, 438-451. [CrossRef]

16. Gadd, H.; Werner, S. Achieving low return temperatures from district heating substations. Appl. Energy 2014, 136, 59-67. [CrossRef]

17. Pirouti, M. Modelling and Analysis of a District Heating Network. Ph.D. Thesis, Cardiff University, Cardiff, Wales, UK, 2013.

18. Olsen, P.; Christiansen, C.; Hofmeister, M. Guidelines for Low Temperature District Heating; EUDP-DEA: Denmark, 2014.

19. Lohmann, S. Einführung in die Software MATLAB-Simulink und die Toolboxen CARNOT und Stateflow zur Simulation von Gebäudeund Heizungstechnik; Fachhochschule Düsseldorf: Düsseldorf, Germany, 2013.

20. Heimrath, R. Simulation, Optimierung und Vergleich solarthermischer Anlagen zur Raumwärmeversorgung für Mehrfamilienhäuser; Ph.D. Thesis, Technische Universität Graz: Graz, Austria, 2004.

21. Heissler, K.M.; Metz, J.; Lang, W. Potenziale von Niedrigtemperaturnetzen zur Steigerung des Anteilserneuerbarer Energien in Quartieren; Technische Universität München-Zentrum für Nachhaltiges Bauen: Munich, Germany, 2017.

22. Duran, P. Technology Pathways for Transforming High Temperature to Low Temperature District Heating Systems in the ENaQ Project. Master's Thesis, Carl von Ossietzky Universität Oldenburg, Oldenburg, Germany, 2020. Available online: https:/ / elib.dlr.de/138337/ (accessed on 27 May 2021).

23. Juhrich, K. CO $\mathrm{CO}_{2}$-Emissionsfaktoren für Fossile Brennstoffe; Umweltbundesamt: Berlin, Germany, 2016.

24. Enkhardt, S. Umweltbundesamt verzeichnet weitere sinkende $\mathrm{CO}_{2}$-Emissionen bei Stromerzeugung. PV Mag. 2020. Available online: https://www.pv-magazine.de/2020/04/08/umweltbundesamt-verzeichnet-weitere-sinkende-co2-emissionenbei-stromerzeugung/ (accessed on 17 July 2020).

25. VDI 2067 Blatt 1. Wirtschaftlichkeit GebäUdetechnischer Anlagen; Grundlagen und Kostenberechnung (Economic Efficiency of Building Installations; Fundamentals and Economic Calculation); Beuth Verlag: Berlin, Germany, 2012.

26. Bundesregierung. Grundlage für CO2-Preis Steht. 2020. Available online: https://www.bundesregierung.de/breg-de/themen/ klimaschutz/nationaler-emissionshandel-1684508 (accessed on 30 November 2020).

27. Mangold, D.; Deschaintre, L. Seasonal Thermal Energy Storage (Task 45); International Energy Agency-SHC: Stuttgart, Germany, 2015.

28. Epp, B. Seasonal pit Heat Storage: Cost Benchmark of $30 \mathrm{EUR} / \mathrm{m}^{3}$. 2019. Available online: https://www.solarthermalworld.org/ news / seasonal-pit-heat-storage-cost-benchmark-30-eurm3 (accessed on 7 December 2020).

29. Matthey, A.; Bünger, B. Methodological Convention 3.0 for the Assessment of Environmental Costs-Cost Rates; Umweltbundesamt: Berlin, Germany, 2019. 